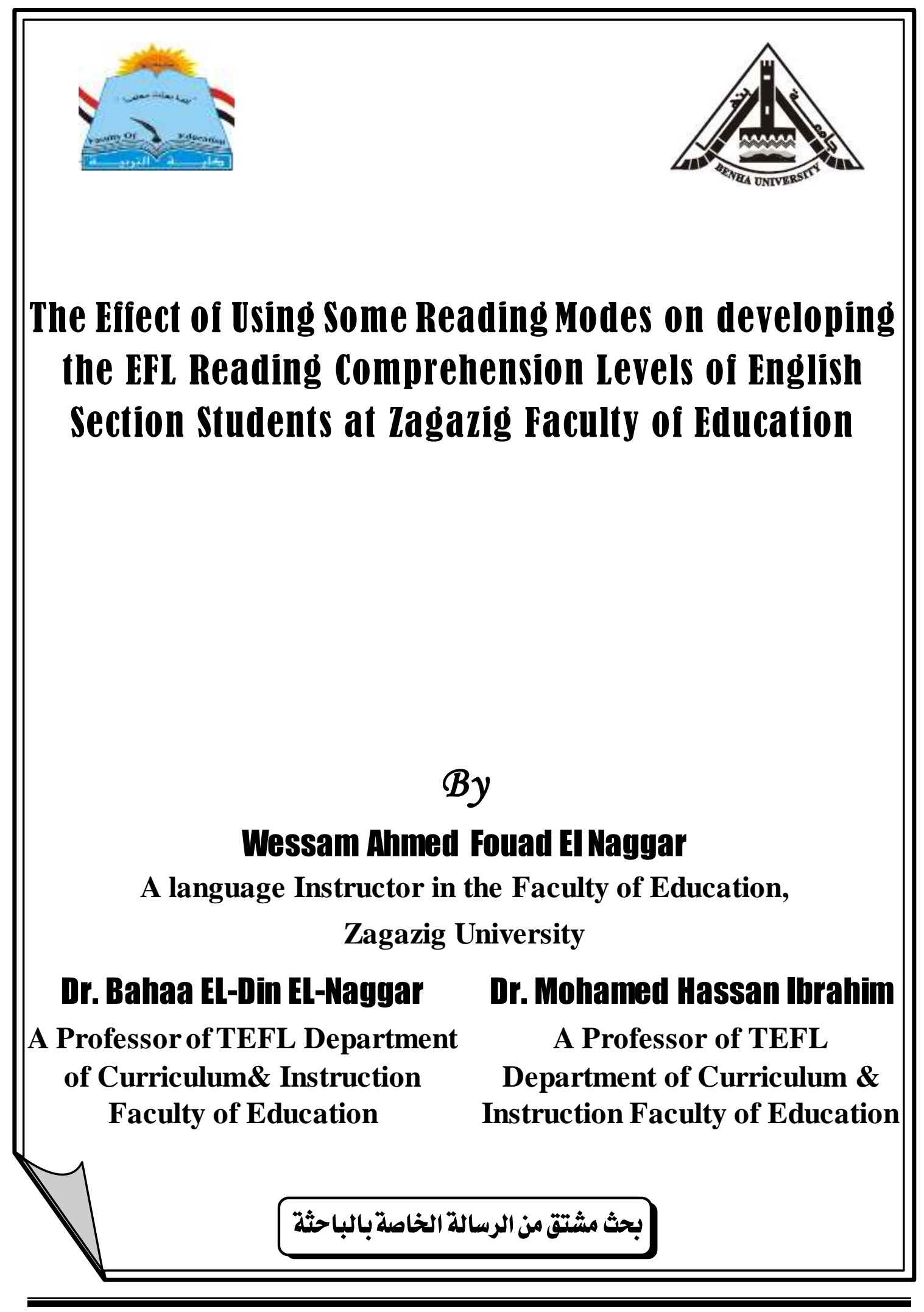




\title{
The Effect of Using Some Reading Modes on developing the EFL Reading comprehension Levels of English section Students at Lagazig Faculty of Education
}

\author{
By \\ Wessam Ahmed Fouad El Naggar \\ A language Instructor in the Faculty of Education,
} Zagazig University

\section{Dr. Bahaa El-Din El-Naggar}

A Professor of TEFL Department of Curriculum\& Instruction

Faculty of Education
Dr. Mohamed Hassan Ibrahim

A Professor of TEFL Department of Curriculum \& Instruction

\section{Ahstract}

The present study investigated the effect of using some reading modes on the reading comprehension levels of English Section Students' at Zagazig Faculty of Education. The study adopted the quasi experimental design. Ninety of 1st year freshmen English Section students at Zagazig Faculty of Education was randomly selected and divided into three groups. Thirty students were chosen for each group. Group one used multimodal printed texts, group two used non- printed multi modal texts, and group three used printed and non- printed multi modal texts. The fourth group received the regular way of teaching. All the participants in the three experimental groups and control group completed the reading comprehension test as pre -post administered for the purpose of data gathering and analyzing. A three likert scale was designed for measuring the effect of reading modes on developing reading comprehension levels and applied them before and after the treatment. Finally, the results of the study approved that reading modes was effective on developing reading comprehension levels.

Keywords: reading modes, reading comprehension level. 


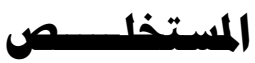

تحددت مشكلة الدراسة الحالية فى أن بعض طلاب الفرقة الأولى شعبة اللغة الانجليزية

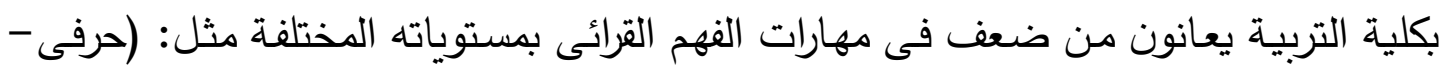

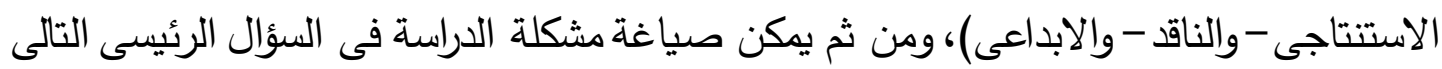

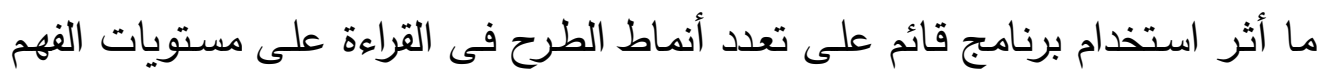

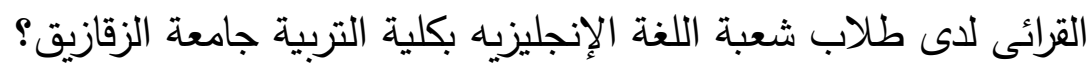
ويتفرع من ذلك الأسئلة الفرعية التالية:

1- ما مهارات الفهم القرائى الاربعة المناسبة لطلبة الفرقة الأولى شعبة اللغة الانجليزيه؟

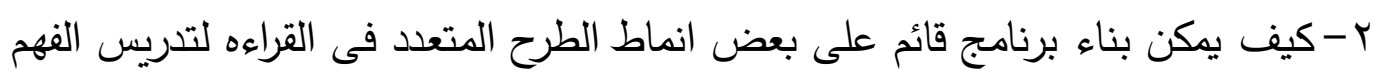

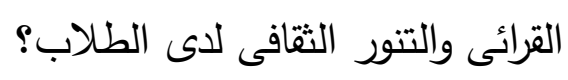

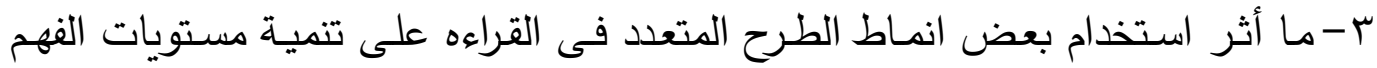

$$
\text { القرائى لدى الطلاب؟ }
$$

اقتصرت الدراسة الحالية على الحدود التالية:

$$
\text { ا-الحسلدود البشــريــة: }
$$

هجموعة من طلاب الفرقة الأولى شعبة اللغة الإنجليزية، وقد تم إختيار الفرقة الأولى الفى

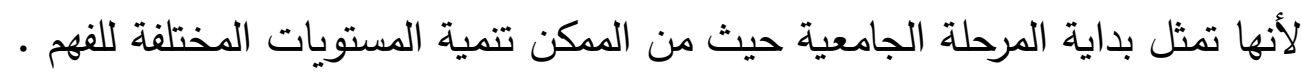

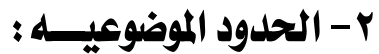

أ) أنماط الطرح المتعدد فى القراءه تحددت بالرجوع الى الإطار النظرى واستثارة الدحكمين.

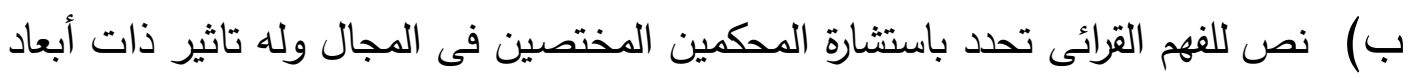
ثقافية على الطلاب.

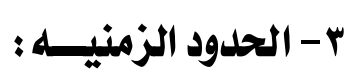

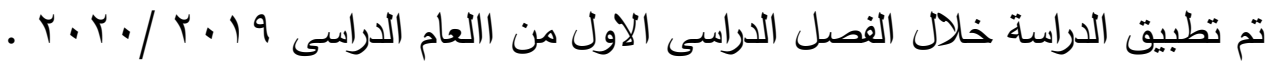

سعت الدراسة الحالية الى التحقق من صحة الفروض التالية:

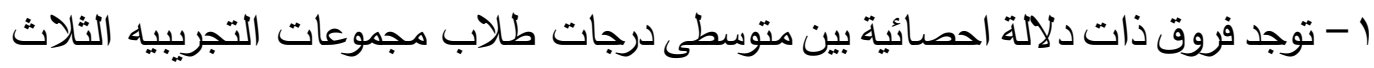

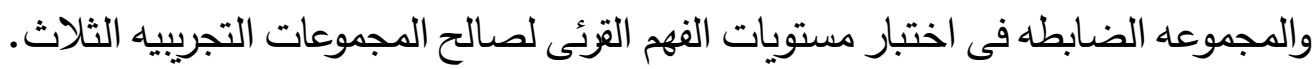

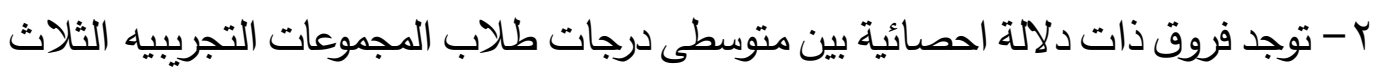
فى التطبيق القبلى والبعدى فى اختبار مستويات الفهم القرئى لصالح التطبيق البعدى. 
ץ- توجد فروق ذات دلالة احصائية بين متوسطى درجات طلاب المجموعات التجرببيه الثلاث فى التطبيق البعدى فى اختبار مستويات الفهم القرئى لصالح المجموعة التجريبيه الاولى...

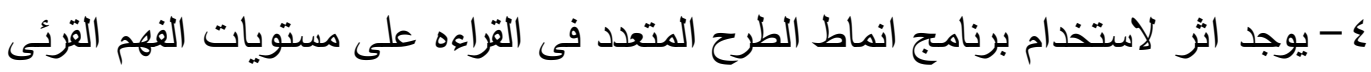
لدى طلاب الفرقه الاولى كلية التربيه جامعة الزقازيق.

\section{أهمية الدراسة اجراءات الدراسية:}

ا-تم مسـح الادبيات والدراسـات السـابقة المرتبطة (انماط الطرح المتعدد ومهارات للفهح

$$
\text { القرائى الاربعة) لإعداد: الإدات }
$$

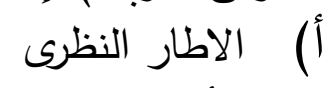

ب) الأدوات الخاصه بالدراسة (اختبار مستويات الفهم القرائى) بواسطة الباحثه وعرضـه

$$
\text { على المحكمين. }
$$

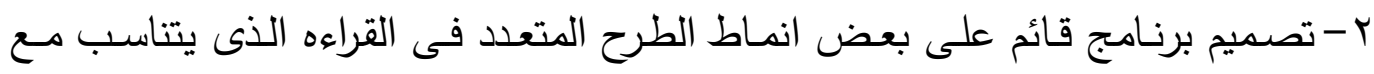
الثلاث مجموعات التجريبيه وعرضده على الخبراء واجراء التعديلات المناسبة.

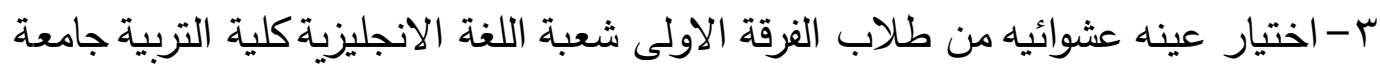

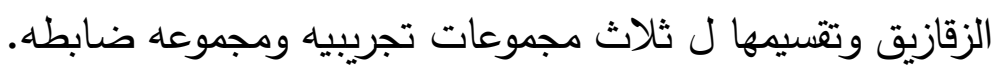
ع - تطبيق اختبار الفهم القرائى على ثلاث مجموعات التجريبيه والمجموعه الضابطه تطبيق قبليا. ه- تطبيق برنامج الطرح المتعدد فى القراءه بواسطة الباحثة على المجموعات التجريبية الثلاث بينما تدرس المجموعه الضابطه بالطريقة المعتادة.

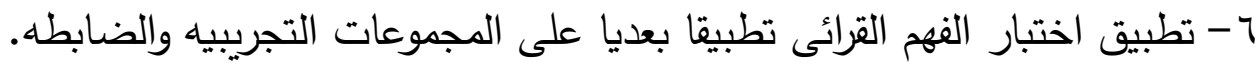

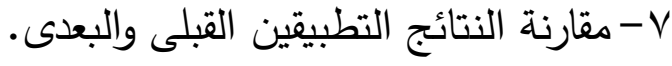
1 - معالجة النتائج احصائيا. 9- مناقشة النتائج وتفسيرها، ثم تقديم التوصيات واتهات والمقترحات.

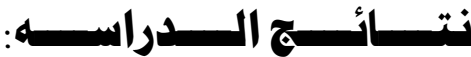

توصلت الدراسة الى مجموعة من النتائج ابرزها ما يلى:

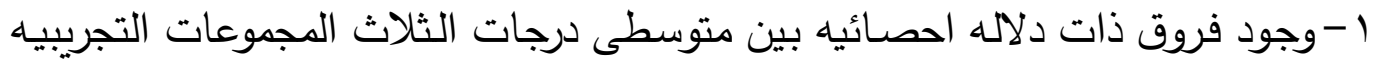

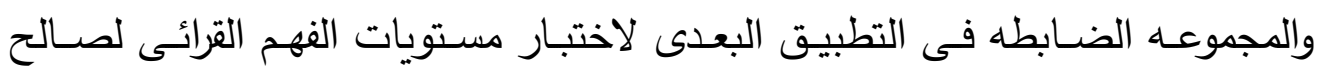
المجموعات التجريبيه الثلاث.

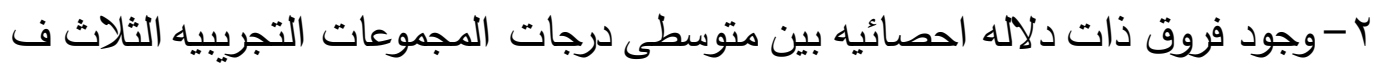
التطبيق القبلى والبعدى لاختبار مستويات الفهم القرائى لصالح التطبيق البعدى.

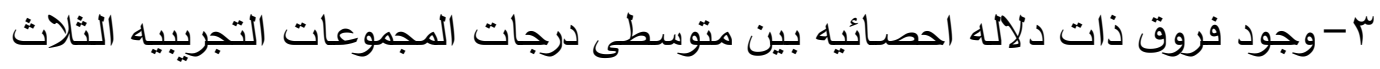
فوالبعدى لاختبار مستويات الفهم القرائى لصالح المجموعة التجريبيه الاولى دلى داته ع - توجد فاعلية للبرنامج القائم على انماط الطرح المتعدد فى القراءه على مستويات الفهح القرئى لدى طلاب الفرقة الاولى كلية التربية جامعة الزقازيق. 


\section{Introduction}

English is the mean of international communication. EFL learners as a foreign or a second language use it to achieve different communicative goals. It is the most language commonly used around the world, in books, newspapers, magazines, radio, television, movies and the Internet. English becomes a real challenge. Reading is considered one of the most important skills which language learners should master. Reading is very important for students because it helps them to understand the world around them, communicate and understand what is communicated. EFL learners have many different texts to read, such as textbooks or other extracurricular reading materials. It is through reading that they acquire much of their knowledge and understanding of different subject areas.

Thus, it is essential for EFL learners to acquire reading comprehension skills in order to understand what they read. Chang and Gould (2008) asserted that reading is considered one of the most essential components of language development. It helps to build vocabulary and leads to lifelong learning and improvement in English language skills. Because EFL learners use different skills to understand meaning from any written texts, they don't decode words with sentences, but also think and comprehend what they read. So, comprehension also requires constructing meaning through integrating text information and students' relevant knowledge (Nation and Angell, 2006). So, reading comprehension can be considered as one of the most important types of reading. According to Macaro and Erler, (2008), reading comprehension involves (a) decoding author's text through processing letters, words, and sentences; and (b) comprehension which includes integrating this information and constructing a mental representation of the text content.

According to Brassell and Rasinski (2008), reading comprehension can be classified into four levels. They are literal, inferential, critical and creative levels. Literal level requires reader to recall facts, names, and things stated in the text. Inferential level allows the readers to suggest relevant additional information based on the text and personal experience 
such as drawing inferences and predicting the difference between fact and opinion. Critical level involves evaluating or making judgments, and recognizing the logic of the arguments. Creative level involves going beyond the material presented by the author such as problem solving and providing new ideas, new insights and original constructs.

In this respect, recent researches on reading comprehension skills have declared the importance of developing EFL reading comprehension skills. Many researches also assured the importance of reading comprehension at the university stage such as Chou, 2011 Elgarawany, 2010; Floris and Divina 2009; Reza and Mohmood, 2013; Williams et al., 2011; Zuo, 2011. Thus, the current study investigated the effect of some reading modes on developing the reading comprehension levels of $1^{\text {st }}$ year freshmen English Section Students at Zagazig Faculty of Education.

Although great efforts have been exerted to develop the teachinglearning process of English, EFL programs still fail to provide as expected. The EFL learners' proficiency in English also is still poor and below expectation. This study investigated the challenges encountered in teaching English in the Arab World countries concerning reading comprehension levels. The researcher tried to help 1st year freshmen students at faculty of education to improve their reading comprehension levels through using different reading modes.

To document the problem, the researcher has reviewed the previous studies. Foreign Studies have asserted the use of reading modes and how they have affected the process of learning English language in general and the process of reading comprehension levels as follows: Schieble(2009), Ganapathy (2016), Baharani and Ghafournia (2015), Manoli and Papadopolou (2013), Romero (2012), Biria and Boshrabadi (2014), Borton (2008), Julian (2010), Vanrala and Jalkanen (2010), Adwu (2012), Lee (2014), Becher(2014), Bao(2017), Kitson(2011).Also, Abd Wahab (2016), El- Sayed (2017), Elgarhy (2016) explained that EFL students have poor performance in reading comprehension skills. The current study would be an attempt to utilize some reading modes to develop reading comprehension skills in EFL 1st year freshmen faculty of education students. 
Reading comprehension has different modes such as printed multimodal modes, non-printed multimodal modes, and both printed and non- printed modes. In general, these types enhance the reading comprehension levels. In this respect, Tanner (2014) explained how peculiar well-suited printed modes are for the reading brain. In fact, there are no genetic or biological structures dedicated solely to reading. Instead, human beings read by joining neural structures originally developed for vision, object recognition, and spoken language to the processes of letter and word recognition and the short-term memory storage necessary for sustained thought.

Walsh (2015) explained the first modes as that the reading process with print-based texts involves different levels of decoding, responding and comprehending at affective and cognitive levels, critiquing and analyzing. Reading is a stable interaction between reader and text. There are some differences between reading print based modes and non-printed modes. Non- printed modes like I phone, e-book, smart phone computers, etc. require an online processing such as reacting to sound effect, animated icons and using the screen (Walsh, 2011).

Walsh (2009) illustrated the third modes; as these texts that have more than one mode. These modes are print and image or print, image, sound and movement. A multimodal text is often a digital text but can be a book, such as picture book, information text or graphic text. Multimodal texts need the processing of more than one mode and the recognition of the integrations between modes. This process is different from the linear reading of print-based texts.

The need for this current study was clarified as a result of the following reasons; a) most of the reviewed literature and previous studies assured the great impact of the reading modes on the reading comprehension levels b) through the researcher experience as a language instructor in the faculty of education, she observed that some of the EFL $1^{\text {st }}$ year freshmen students at faculty of education have problems in the reading comprehension levels. C) Reading modes have never been fully investigated in the Egyptian 
ELT context. Furthermore, a pilot study was carried out during the second semester academic year (2016-2017) to check students' mastery of the skills of reading comprehension levels to a group of $30 \mathrm{EFL} 1^{\text {st }}$ year freshmen students at faculty of education, Zagaig University.

The results of the reading comprehension test released that the percentage of the students' response to these skills was less than $50 \%$. The students have poor level of reading comprehension levels. To tackle this problem multimodality reading modes could be effective in reading comprehension levels. The EFL1st year freshmen students could overcome the obstacles they encounter during reading comprehension tests.

Working with multimodal reading modes in the EFL classroom can be used to develop not only students' reading skills but also their writing, speaking and listening competence. These modes could help consolidate a holistic approach to teach four skills of English (D'Andera, 2010). The theory of multimodality developed through the work done by Kress and Leeuven $(2001,2006)$. Multimodality has contributed to understand how different modes of communication language such as images, graphs, sound, music, gestures, etc.

Using multimodality in the class makes learning remains for a long time and changes students' motivation and attitudes towards learning. Marie (2016) assured that multimodal classes facilitate the learning process and make students creative, active and autonomous while they learn. Also, Marie (2016) emphasized that students are the leaders in the teaching learning process. They are be prepared to take decisions constantly about different things such as the text they choose, their essay they write, the topic of oral presentation, the comments they write through Facebook.

Multimodal reading modes in this current study divided into three groups; (multimodal printed texts group, non- printed multimodal texts group, and both printed and non- printed multimodal texts group). The 
current study investigated which one of these groups would be the most effective in overcoming the difficulties of reading comprehension levels of EFL $1^{\text {st }}$ year freshmen faculty of Education Zagazig students.

\section{Statement of the problem:}

On the basis of the above introduction and in the result of the pilot study it could be concluded that EFL $1^{\text {st }}$ year freshmen students have problems in reading comprehension levels. Using the multimodal reading modes could be suggested as a possible way to remedy this problem. Accordingly the problem under investigation could be stated in the following main question and the respective sub questions;

What is the effect of using some reading modes on developing the reading comprehension levels of English students at Zagazig Faculty of Education?

The main question is sub-divided into the following sub- questions;

1- What are the suitable skills of reading comprehension levels for the EFL $1^{\text {st }}$ year freshmen students in the faculty of Education?

2- What are the features of the some multimodal reading modes for teaching reading comprehension for EFL $1^{\text {st }}$ year freshmen students in the faculty of Education?

3- To what extent is the multimodal reading modes effective in developing reading comprehension levels?

\section{Design and sample:}

a) In this study the quasi experimental design would be adopted.

b) For the participants; three experimental groups of students were drawn from the EFL 1st year freshmen English department students. The gender was disregarded through the intervention period.

\section{The Study Aims:}

The present study aimed at:

1- Developing some reading comprehension levels.

2- Investigating the effect of some multimodal reading modes program on the reading comprehension levels.

3- Comparing the three groups of multimodal reading modes to each other. 


\section{Significance of the study:}

The results of this study were hopefully expected to be useful to:

\section{1- EFL First year, Faculty of Education students:}

a) It could enable students to develop their reading comprehension levels.

b) It could help students to become active, self- motivated, selfesteemed, self -confident.

\section{2- EFL Instructors:}

a) It could provide them with a list of EFL reading comprehension skills that are appropriate for EFL prospective teachers.

b) It may be beneficial in finding out which multimodal reading modes is more efficient for improving students' reading comprehension levels.

\section{3- Curricula designers:}

Through presenting some multimodal reading modes that may help in EFL curricula development and to enrich modes books with activities, tasks, strategies and techniques which enhance students' EFL reading comprehension levels.

\section{The study Instruments:}

1- Reading comprehension levels checklist

2- Reading Comprehension levels Test

3- Rubric for correcting the test

\section{Hypothesis:}

Examining the previous literature and previous studies, the hypotheses of the current study could be formulated as follows:

1- There would be statistically significant differences between the mean scores of the three experimental groups (multimodal printed group- non-printed multimodal group - and both multimodal printed and non-printed group) and the control one in the post administrations of the overall reading comprehension levels' test in favor of the experimental groups' results. 
2- There would be statistically significant differences between the mean scores of the three experimental groups in pre and post administrations of the overall reading comprehension levels' test in favor of the post administration's results.

3- There would be statistically significant differences between the mean scores of the three experimental groups in the post administrations of the overall reading comprehension levels' test in the favor of the first experimental group.

4- The multimodal reading modes program has a positive effect on improving students' EFL reading comprehension levels.

\section{Procedures of the study:}

In the basis of the statement of the problem and its sub questions the procedures would be as follow:

1- Reviewing the relevant literature and previous studies related to reading comprehension levels, cultural literacy questionnaire to prepare: a. the theoretical background and

b. the instruments of the study.

2- Designing some multimodal reading modes and its content would be subjected to thorough discussion with a number of experts.

3- Drawing the study sample from the EFL1st year freshmen students and dividing them into three groups at the Faculty of Education.

4- Pre-administering the study instruments to the three treatment groups.

5- Teaching the content of multimodal reading modes program by the researcher to treatment groups.

6- Post- administering the study instruments to the three experimental groups.

7- Submitting the obtained results to the convenient statistical methods to be analyzed.

8- Discussing and interpreting the results.

9- Drawing conclusions, and providing recommendations and suggestions for further research. 


\section{Study delimitations:}

This study was limited to

a) A sample of ninety EFL ( $1^{\text {st }}$ year department of English students in the faculty of Education Zagazig University for the following reasons:

- First year EFL students are not trained well to read in English because they had not the chance to practice some reading modes during secondary stage.

b) Multimodal modes that would be determined through- out the review of relevant literature and consultation of jury members. (Multimodal printed- texts, non-printed multimodal texts, and both printed and non- printed multimodal texts).

c) The reading material would be determined after consulting with experts under the consideration that it must be bound in cultural effects. The Old Man and the Sea was chosen to be the reading material because this novel was taught to them and it had many good morals and values which were near to our culture and suitable for the EFL 1st year freshmen students at faculty of education Zagazig University.

\section{Resulits of the Study:}

The results of the treatment groups and non- treatment one in the overall pre- reading comprehension test, indicated that the students of the four groups were almost homogeneous, where there were no significant differences of the four groups in the pre- test before the administering the treatments of the study. These results could be attributed to the following reasons:

1- Following the same traditional methods in teaching English.

2- Students couldn't have time to practice EFL reading comprehension levels.

3- Students couldn't participate at any multimodal reading modes program in any lectures. 
After experimentation, the results revealed that the level of the treatment groups who were taught using multimodal reading modes program were higher than those of the non- treatment one who received the traditional methods of teaching in the post administration of EFL reading comprehension levels. These results are similar to the results of Vaarala and Jalkanen (2010). Moreover, the results revealed that the level of the treatment groups who were taught using multimodal reading modes program in the post test were higher than in the pre- test of reading comprehension levels. These results are similar to the results of Biria and Boshrabadi (2014) and Romero (2012).

In addition, the results revealed that the level of the students of the first treatment group in the post test surpassed those of the second and the third treatment groups in the overall EFL reading comprehension levels because this group received different and various activities, tasks and strategies (debates, Jigsaw, hot seating, group experts and book art). These activities help the first experimental groups to develop their level in EFL reading comprehension levels. These results are similar to the results of Baharani and Ghafournia (2015).

Finally, these results indicated that the multimodal reading modes program used in the present study had a positive effect on the EFL1 ${ }^{\text {st }}$ year freshmen English Department Students' reading comprehension levels in the three treatment groups. These results may be attributed to exposing the groups to a number of techniques, activities and strategies; (debates, hot seating, role play, group experts, KWL Charts, Venn diagram to realize similarities and differences, working through pair work and group work, activating prior knowledge, visualizing, retelling, answering questions, making connections) through which students had a full chance to express themselves loudly and proudly to overcome the shyness.

Moreover, some students had ambitious and desire to share in the program which encouraged them to develop EFL reading comprehension levels. Students had important roles to get the information by themselves, give their opinions and use their imagination to create new 
things. That's why the role of the students in this program became higher. There were also successful factors that helped students develop their EFL reading comprehension levels (e. g. self- confidence, motivations and the level of ambition).

Regarding the relationship between the three groups, the results revealed that the multimodal printed group outperformed the first one in the EFL overall reading comprehension levels for many reasons. The first group received many activities and tasks which have a vital role in developing the dependent variables such as (drawing picture book from their imagination about the events of the novel, hot seating, debates, jigsaw strategy, group experts, mind mapping, KWL Chart). In addition to the previous reasons the classroom atmosphere was very important as applying the above tasks and activities, students' idea, viewpoints and thoughts were arranged and valued through a motivating environment.

The present study coincided with many studies related to multimodal reading modes to develop reading comprehension level (Bao, 2017; Vaarala and Jalkanen, 2010; Biria and Boshrabadi, 2014; Romero, 2012; Manoli and Papadopoulou.2013; Baharani and Ghafournia, 2015). This asserted that multimodal reading modes had a great and positive effect on developing reading comprehension levels.

On the other hand, the following studies used multimodal reading modes with different variables and different samples (Lee, 2014; Julian, 2010; Borton, 2008). Moreover, these results of the present study were consistence with results of (Baharani and Ghafournia, 2015; Borton, 2008; Biria and Boshrabadi, 2014) whose studies proved that multimodal reading modes had better impact and create positive attitudes and feeling towards the reading comprehension levels.

To sum up, the hypotheses of the study were accepted. Using the multimodal reading modes program was effective in developing reading comprehension levels for the EFL 1st year freshmen English Department students. The results revealed that the first group (multimodal printed group) was the best one of the second group (non-printed multimodal group) and the third one (multimodal printed and non- printed group). 


\section{References}

Abdel-Hamid, H. (2010). The effectiveness of using annotation strategy in developing some reading comprehension skills among EFL college students. M.A Thesis. Faculty of Education, Benha University.

Abdel-Haq, E. (2008). Cognitive apprenticeship: Implications for teaching EFL reading comprehension skills. Faculty of Education Journal, Benha University, 18(76), 1-31.

Brassell, D., \& Rasinski, T.R. (2008). Comprehension that works: Taking students beyond ordinary understanding to deep comprehension. Huntington Beach ,CA: Shell Education.

Chou, p. (2011). The effects of vocabulary knowledge and background knowledge on reading comprehension of Taiwanese EFL students. Electronic Journal

D'ANDREA, L. (2010). Using writing to develop communicative competence in the foreign language classroom. BELT JOURNAL, Porto Alegre, v. 1, n. 2 , p. 139-146.

El-Garawany, M. (2010). The effects of repeated reading strategies on developing oral reading fluency and reading comprehension among EFL prospective

Floris, F. \& Divina, M. (2009). A study on the reading skills of EFL university students. TEFLIN Journal, 20(1), 37-47.

KRESS, G., van LEEUWEN,(2006) T. Reading images: the grammar of visual design. (2ed.). Languages. Mentouri UniversityConstantine.London/NY: Routledge,.

Macaro, E., \& Erler, L. (2008). Raising the achievement of youngbeginner readers of French through strategy instruction. Applied Linguistics, 29 (1), 90-119. 
María Martínez L. (2016). International Journal for 21st Century Education, vol. 3, Special Issue 'Language Learning and Teaching', 2016, 77-88.

Martin-Chang, S.Y., \& Gould, O.N. (2008). Revisiting print exposure: Exploring differential links to vocabulary, comprehension and reading rate. Journal of Research in Reading, 31, 273- 284.

May, C. (2010). Explicit instruction of reading strategies that enable EFL learners to achieve comprehension in reading. M.A Thesis. Faculty of Letters and Languages. Mentouri University-Constantine.

McRae, S. (2012). Utilizing the interactive reading model in a continuing education course. MATESOL Collection. Paper 540.Mueller, Marlies. (on line) "cultural literacy and foreign language pedagogy" A.D.L.F bulletin Winter 1991.www.adf/.org/adf/bulletin/v22n2/Jan30,2001) http://dataworks-ed.com

Nation, K., \& Angell, P.(2006). Learning to read and learning to comprehend. London Review of Education, 4, (1), 77-87.

Pang, E. S., Muaka, A., Bernhardt, E. B., and Kamil, M. L. (2003). Teaching reading. Brussel: The International Academy of Education (IAE).

Polistina ,K.(2003). towards environmentally sustainable lifestyle through outdoor leisure, In A. Ibetson ,B. Waston and M. Ferguson (eds) sport, lesuire and social inclusion. East bourne: lesuire studies association

Reading , 34 (2), 215-231.Research Studies in Language Learning , 2 (3), 67-80.

Reza, G., \& Mahmood, D.(2013). Sociocultural theory and reading comprehension: The scaffolding of readers in an EFL context. International Journal of Foreign Language Teaching, 8 (1), 108- 115. 
Snow, C. (2002). Reading for understanding: Towards AR\&D program in reading comprehension. Washington, DC: RAND Reading Study Group.teachers. M.A Thesis. Faculty of Education, Minufiya University.

Vellutino, F. R. (2003). Individual differences as sources of variability in reading comprehension in elementary school children. In C. Snow \& A. Sweet(Eds.), Rethinking reading comprehension (pp. 51-81). New York, NY: The Guilford Press.

Williams, R. S., Ari, O.,\&Santamaria, C. N. (2011). Measuring college Students' reading comprehension ability using cloze tests. Journal of Research in

Yang, Y. (2002). Reassessing readers' comprehension monitoring. Reading in a Foreign Language, 14, 18-42.

Zuo, W. (2011). The Effects of cooperative learning on improving college students' reading comprehension. Theory and Practice in Language Studies, 1 (8). 